\title{
The Local Content Act, 2010 and Manpower Development Policy in Nigeria: How Far so Far?
}

\author{
Christian C. Obeagu*
}

Ph.D., Senior Lecturer, Department of Public Law, Faculty of Law, Enugu State, University of Science and Technology (ESUT), Enugu, Nigeria

DOI: $10.36348 /$ sijlcj.2020.v03i11.004

| Received: 20.10.2020 | Accepted: 01.11.2020 | Published: 07.11.2020

*Corresponding author: Christian C. Obeagu

\section{Abstract}

This paper examined the Local Content Act, 2010 in the oil and gas industry in Nigeria and its operability and realisation of the aims and objectives. Human capacity-building and development of the local populace by giving opportunity to Nigerians to be effectively involved in the industry as a cardinal objective was so far given reasonable attention, as against the hitherto monopoly of the industry by foreigners. Job opportunities resulted and taken by Nigerians for skilled and unskilled workers; even as many Nigerians received various trainings for skills acquisition. The paper noted gaps to be filled as the level of expertise of Nigerians still fall short of expectation. It recommended measures to improve the realisation of the objectives of the Act such as aggressive investment in research and development to enhance transfer of technology.

Keywords: realization, Nigerians, expectation, technology.

Copyright $\odot$ (2020 The Author(s): This is an open-access article distributed under the terms of the Creative Commons Attribution 4.0 International License (CC BY-NC 4.0) which permits unrestricted use, distribution, and reproduction in any medium for non-commercial use provided the original author and source are credited.

\section{INTRODUCTION}

By April 2020, the Local Content Act $\left[{ }^{1}\right]$ had been in operation for a decade in the oil and gas industry in Nigeria. The Act has as its main thrust, ensuring the existence of "Nigerian Content" in the sphere of oil and gas business in Nigeria. Accordingly, Section 106 of the Act defines "Nigerian Content" to mean the quantum of composite value added to or created in the Nigerian economy by a systematic development of capacity and capabilities through the deliberate utilization of Nigerian human, material resources and services in the Nigerian oil and gas industry. Thus, the Act imposes a deliberate and conscious effort on all regulatory authorities, operators, contractors, subcontractors, alliance partners and other entities involved in any project, operation, activity or transaction in the industry to make use of Nigerian human resources of all cadres, both skilled and unskilled where relevant $\left[{ }^{2}\right]$. The duty imposed under Section 2 makes it imperative for critical stakeholders and operators to develop Nigerians by training to be able to qualify in carrying out certain tasks and obligations in the industry. This paper will consider whether the Local Content Act made provisions for

${ }^{1}$ No.2, 2010 was signed into Law on $22^{\text {nd }}$ day of April, 2010 by President Goodluck Ebele Jonathan.

${ }^{2}$ Section 2. manpower development otherwise called training of Nigerians; objectives of such manpower development; assess the workability or applicability in this regard; then draw a conclusion and make recommendations.

\section{Locating Manpower Development Provisions}

While Section 2 makes Nigerian Content as management philosophy for project execution in the industry, it goes ahead to impose obligation on all those involved in project execution, directly or indirectly to consider Nigerian Content as an essential component. In order to ensure that Nigerian Content really counts in project execution and all other aspects of industry activity, the Act made provisions for manpower development in areas of lack of skilled Nigerians to be able to fit in to handle such tasks. This is to enable the attainment of the overall objectives of the Act. Such manpower development provisions will now be examined and they include the following:

\section{First Consideration for Employment and Training} Section 28(1) of the Act provides that,

Subject to Section 10 (1) (b) of this Act, Nigerians shall be given the first consideration for employment and training in any project executed by any operator or project promoter in the Nigerian oil and gas industry. 
Subsection 2 provides that the Board shall ensure that the operator or project promoter maintains a reasonable number of personnel from areas it has significant operation.

It is clear from this Section that whenever there is need for employment and as well for training of personnel as workforce in the area of concern, the concerned operator or project promoter must give first consideration to Nigerians. There is no doubt that such policy if implemented to the letter would enhance rapid manpower development and empowerment of Nigerians.

\section{Submission of Employment and Training Plan}

Section 29 provides that the Plan submitted by any operator or project promoter for any project shall contain an Employment and Training Plan (E and $\mathrm{T}$ Plan) which shall include -

(a) An outline of the -

i. hiring and training needs of the operator or project promoter and operator's major contractors with a breakdown of the skills needed;

ii. anticipated skill shortages in the Nigerian Labour force;

iii. project specific training requirements; and

iv. anticipated expenditures that will be made directly by the operator in implementing the $\mathrm{E}$ and $\mathrm{T}$ Plan as a forecasted and actual expenditure; and

(b) A time frame for employment opportunities for each phase of project development and operations, to enable members of the Nigerian workforce to prepare themselves for such opportunities.

This provision is visionary and a laudable one indeed. It anticipates shortages of skilled manpower among Nigerians and makes it obligatory on operators not only to develop Nigerian human resources in different cadres but also within a time frame for employment opportunities to be effectively and efficiently operated by Nigerians.

\section{Training of Nigerians - Section 30}

This Section provides that:

Where Nigerians are not employed because of their lack of training, the operator shall ensure, to the satisfaction of the Board, that every reasonable effort is made within a reasonable time to supply such training locally or elsewhere and such effort and the procedure for its execution shall be contained in tile [sic] operator's E and T Plan.

This provision is meant to check overt or covert undermining of the realization of the manpower development policy of the Act by ensuring that there was real plan for and concerted effort at providing such training but for some unavoidable contingencies or supervening factors.

\section{Requirement for Succession Plan - Section 31}

This is a most ambitious and result-oriented provision in the chain of manpower development policy envisaged by the Act, particularly Subsection (1) and (2). It provides thus:

S.31 (1) for each of its operations, the operator Shall submit to the Board a succession plan for any position not held by Nigerians and the plan shall provide for Nigerians to understudy each incumbent expatriate for a maximum period of four years and at the end of the four year period the position shall become Nigerianised.

(2) All indigenous (Nigeriansed) positions shall attract salaries, wages and benefits as provided for in the operators' conditions of service for Nigerian employees.

This provision clearly anticipates that following due and diligent manpower development through training of Nigerians who would become skilled and experts in various cadres, the expatriates would eventually leave and their positions ultimately taken over by Nigerians. This is another demonstration of 'Nigeria First Policy' envisaged by the Act to empower Nigerians to take charge of their oil and gas business from foreign nationals.

\section{Aims and Objectives of Manpower Development Policy}

The manpower development policy has certain aims and objectives in view. Some of these are immediate (short term) while others are later (long term) for wholesale realization of the aims and objectives of the Act.

\section{Immediate Objectives of the Local Content Act}

The immediate or short term objectives of the Act include the following:

\section{Employment of Nigerians}

One of the cardinal objectives of the Act is geared towards providing employment opportunities for Nigerians, especially at junior and intermediate levels by operators and companies in the oil and gas industry. This is provided for in Section 35 of the Act which is exclusive only for Nigerians. There is no doubt that this is meant to reduce unemployment rate among Nigerians.

\section{Training of Nigerians in skills acquisition}

The Act is keen on providing quality training for indigenous Nigerians in skills acquisition and technical knowledge to become experts in various areas 
of operation in the industry. Sections 29 and 30 specifically provide for such trainings. The essence is to empower those Nigerians to be able to effectively participate in the running of the industry and eventually take over from the expatriates at their exit.

\section{Development of intellectual capacities}

The training provisions of the Act obviously envisage intellectual development of Nigerians through provision of scholarship programmes and sponsorship to all deserving indigenes of Nigeria in all cadres of academic learning and institutions both local and foreign. This aspect of training is an important human capital development programme that is invaluable to national development generally.

\section{Feeling of sense of belonging}

The expatriate partners in the oil industry often treat local Nigerians as outsiders and adjuncts, in most cases, in terms of being stakeholders in the scheme of affairs. In essence, many indigenous people are not given opportunity to take part in the running of the affairs of the industry.

However, the manpower development policy aims at reversing this trend by integrating indigenous Nigerians in the day to day running of the affairs in the industry, thus giving them the sense of belonging and self-esteem as stakeholders in the operation of the naturally-endowed resources in their country.

\section{Enhanced earning/personal income}

Participation in the scheme of affairs in the oil sector by Nigerians such as being employees, contractors, artisans, casual labourers and so forth would no doubt enhance the earnings or income of those Nigerians. This would unarguably enhance the living standard of the people, elevate their social status and make life much better and happier. Under such circumstances, the people would become proud Nigerians and give out their best.

\section{Long-term Objectives of the Local Content Act} the following:

The long-term objectives of the Act include

\section{Complete take-over of management by Nigerians}

The Act contemplates that sometime in the near future, full management of the oil sector would be by Nigerians on the exit of the expatriates. This is the reason why Nigerian Content is the management philosophy for project execution under Section 2 of the Act.

Besides, Section 31 of the Act makes it imperative for requirement of succession plan for any position not held by Nigerians.
Competitive operators by international standards

Becoming effective and competitive operators in the oil sector by global best practice by indigenous Nigerians is at the root of the policy objective and implementation under the Act.

Thus, Section 41 (1) mandates the Minister to make regulations setting out targets to ensure full utilization and steady growth of indigenous companies engaged in exploration, seismic data processing, engineering design, reservoir studies, manufacturing and fabrication of equipment and other facilities and provide support services for the oil and gas industry in Nigeria.

There is no doubt that such measure is geared towards not only complete take-over of management and administration of the sector by local Nigerians, but to enable proficiency and competitiveness.

\section{Actualization of technology transfer}

Realization of technology transfer from the expatriate partners to Nigerians remains a cardinal objective of the Local Content Act. It is in this regard that Section 44 of the Act provides that the operator shall submit to the Board annually a plan ... setting out a programme of planned initiatives aimed at promoting the effective transfer of technologies from the operator and alliance partners to Nigerian individuals and companies.

The motive behind this provision is for Nigeria and Nigerians not to remain perpetual appendages to the foreign partners in the management and control of the oil and gas industry. This obviously is to strengthen the succession plan for indigenous Nigerians envisaged by the Act at the exit of the expatriates in order not to be a succession without success. This is an ambitious and laudable dream.

For example, our refineries over the years are still in shambles for the reason of operating far below capacity as a result of non-repairs and maintenance. This is largely because these repairs and maintenance cannot yet effectively and efficiently be done by local Nigerians but by the expatriates who may charge prohibitive cost for the job of putting those refineries operating in full capacity.

Besides, this sorry state of our refineries further make importation of refined petroleum for our local consumption imperative, with is attendant loss of huge amount through subsidization by the government.

NNPC report recently published supports this point. According to the source:

Nigeria has continued to suffer value over its refusal to refurbish its moribund refineries and inability to effectively police its oil and gas assets, as data obtained yesterday, from the 
Nigerian National Petroleum Corporation, $N N P C$, revealed that the country lost $N 38.26$ billion in November 2019 to fuel subsidy, products theft and unending pipeline repairs... Giving a breakdown of the losses in November, the NNPC stated that it incurred N33.19billon as under-recovery, otherwise known as subsidy for Premium Motor Spirit, PMS; while N88.97 million was lost through petroleum products theft [sic] ... In the previous month, underrecovery gulped $N 29.31$ billion; N659.47 million worth of petroleum products were stolen... [ [ $\left.{ }^{3}\right]$.

\section{The source further noted:}

Also, domestic refining capacity has deteriorated over the years. In some months, none of the refineries processed any crude oil. In 2018, average capacity utilization, ACU, was 8.02 percent, with zero percent capacity utilization, $C U$, recorded in some months. ACU for the first seven months of 2019 stood at 3.68 percent. In summary, domestic refining capacity worsened between 2017 and $2019\left[^{4}\right]$.

\section{Enhancement of national sovereignty}

The driving force of the multi-national corporations is the maximization of profit through the exploitation of labour by capital, that is, the money made in our nation is rather exported home than invested in Nigeria. The implication is that the host nation shall continue to be dependent on their dictations and control through neo-colonialism and imperialism; but with manpower development, the economy would become homegrown and enable the nation hold her head high in the comity of nations.

\section{How far?}

In assessing the workability of realizing the objectives of the Act, one can say so far so good, with a number of achievements, which include:

\footnotetext{
${ }^{3}$ Michael Eboh, 'Nigeria loses N38bn to subsidy, oil theft, pipeline repairs in one month', Vanguard, Wednesday, February 26, 2020, p.16.

${ }^{4}$ Ibid. According to the Nigeria Natural Resources Charter, NNRC report, 'the fact that the refinery capacity utilization had worsened rather than improved within the period under review suggested that the specific objectives outlined in policy documents were wrongly conceived to begin with or may have been abandoned.' Nigeria, indeed, has four refineries with 524 barrels per day capacity; but in the last 20 years have been operating with average capacity utilization hovering between 15 and 25 percent per annum. Consequently, 70-80 percent of national petroleum products demand is met through importation. This does not encourage local content development.
}

\section{One: Intellectual and mental development of} Nigerians

On intellectual and mental development of the local people, there exists a scheme for such. Many local Nigerian students, from secondary school level to even postgraduate level, have benefitted from various scholarship trainings both in local and foreign schools and tertiary institutions. The effect is that more and more Nigerians enjoy free academic training that has resulted in producing great scientists, engineers, political scientists, sociologists, environmentalists, lawyers, medical doctors, and a host of others that are positively impacting on the local population and environment.

\section{Two: Skills acquisition and training}

In terms of skills acquisition and training, some local Nigerians have benefitted and continue to benefit from one training or the other both locally and internationally within the petroleum industry. Such trainees at the end of their training not only become critical operators in the industry but can as well become self-reliant and this positively impact on the Nigerian economy sectorally, and indeed, in wider dimensions indirectly. This is the essence of the Local Content Act, 2010.

Not long ago, the Petroleum Technology Development Fund $\left[{ }^{5}\right]$ trained 15 drilling engineers to boost local content in the sector. According to the source:

Fifteen drilling engineers trained at the French Institute of Petroleum, IFP, in France yesterday in Abuja received their certificates from the Petroleum Technology Development Fund, PTDF. The Acting PTDF Executive Secretary, Mr. Jolomi Arenyeka, presented the certificates to the graduates $\left[{ }^{6}\right]$.

The training was obviously part of the organization's effort to ensure greater participation of Nigerians in the oil and gas industry. In the words of Arenyeka:

The Programme evolved due to the intention of the fund to fill identified gaps and ensure an adequate capacity building in the area of oil and gas drilling/production operations. This is to ultimately enhance Nigerian content development in the oil and gas industry... I am pleased to inform you that all the 15 trainees sponsored for the programme were successful and are today being presented with their certificates $\left[{ }^{7}\right]$.

\footnotetext{
${ }^{5} \mathrm{PTDF}$. 8, 2013, p.11.

${ }^{7}$ Ibid.
}

${ }^{6}$ Gbemudu, E. 'PTDF trains 15 drilling engineers to boost Local content', National Mirror, Friday, February, 
In order to ensure the trainees' maximum utilization in the sector, Mr. Arenyeka said:

The Fund (PTDF) had concluded
arrangements to place the engineers on a post-
training attachment programme at NPDC,
which is the exploration and production
subsidiary of NNPC $\left[{ }^{8}\right]$.

The Acting PTDF Executive Secretary consequently called on all stakeholders in the sector to ensure the engagements of the certified drilling engineers on completion of their post-training attachment $\left[{ }^{9}\right]$.

In a related development, a multinational corporation, Shell Petroleum Development Company Nigeria Ltd graduated 19 Nigerians in skill acquisition in a measure geared towards enhancing the local content in the industry. A source on this issue stated:

In its effort to develop the local content in the oil and gas sub-sector of the economy, Shell Nigeria Exploration and Production Company (SNEPCo) Limited, on Monday, graduated 19 young Nigerians, who the company sponsored in one-month training in offshore support skill acquisition training programme in Oil and Gas related technologies. The ceremony, which took place at LADOL Free Zone, the Lagos Deep Offshore Logistics Base, Offshore of the Lagos Island, Pooled top personalities in the oil and gas sector $\left[{ }^{10}\right]$.

Speakers poured encomia on SNEPCo for its contributions to the Nigerian economy and advised the graduates to cherish and make use of the skills they had acquired in developing themselves and their immediate environment $\left[{ }^{11}\right]$.

According to the General Manager (Operations) of OFSERV Nigeria Ltd, Mr. Dimeji Bassir, the facilitators of the training programme,

...the training of the young Nigerians, drawn from different geographical sections of the country, was a programme under the BONGA North-West project, an initiative of the Federal Government to boost local content through human capital development, with emphasis on equipping young Nigerians with the needed skills in the oil and gas sector $\left[{ }^{12}\right]$.

There is no doubt that given enabling environment, these Nigerian experts and some others who bring in their expertise to bear in the sector would

\footnotetext{
${ }^{8}$ Ibid.

${ }^{9}$ Ibid.

${ }^{10}$ Jupadim, C. 'Shell graduates 19 in skills acquisition', Daily Sun, Wednesday, March 13, 2013, p.53.

${ }^{11}$ Ibid.

${ }^{12}$ Ibid.
}

accelerate and broaden economic activities and output, thereby deepening Nigeria's economy from the sector at minimal cost of production.

In a related development, Shell Petroleum Development Company Nigeria Limited graduated 19 Nigerians in skill acquisition in a measure geared towards enhancing the Local Content in the industry $\left[{ }^{13}\right]$.

\section{Three: Attaining increased earning by Nigerians}

The objective of attaining enhanced earnings by Nigerians in the oil sector has started yielding fruits as Nigeria has been ranked among highest paying contract jobs.

According to the source:

Indications of steady progress in the nation's oil and gas sector emerged yesterday as Nigeria was listed for the first time among the highest paying contract jobs in oil and gas sector worldwide. This is coming as the nation advances in its move to increase local participation in the industry through the Nigeria Content agenda of the Federal Government. The latest release by Swift Worldwide Resources yesterday placed Nigeria third and fourth respectively among the ten highest paid contract jobs, which was led by Australia in two different categories $\left[{ }^{14}\right]$.

\section{Four: Creation of more job opportunities}

Creation of more jobs is steadily being achieved, even by indigenous companies. Kaztech Engineering Limited, a local company is outstanding here. The company was reported to have said yesterday that it would invest $\$ 750$ million, about $\$ 120$ billion, in the country between 2014 and 2015. The company noted that the amount will be invested in setting up a pipe coating and pipe rolling mill facility, dry dock and logistics base at the dockyard ... the project will contribute in alleviating the unemployment situation in the country, by creating about 5,000 direct jobs and 20,000 indirect jobs by $2016\left[^{15}\right]$.

\footnotetext{
${ }^{13}$ Jupadim, C. 'Shell graduates 19 in skills acquisition', Daily Sun, Wednesday, March 13, 2013, p.53.

${ }^{14}$ Salau, S. 'Nigeria tops list of highest paying contract jobs in oil, gas sector', The Guardian, Thursday, September 4, 2014, p.7. Swift experts predict that as exploration becomes more competitive across major oil companies, skilled workers in these positions will be drawing even higher compensation.

${ }^{15}$ Eboh, M. 'Local Content: Kaztec to invest $\$ 120$ bn in two years', Vanguard, Tuesday, May 20, 2014, p.26.
}

(C) 2020 |Published by Scholars Middle East Publishers, Dubai, United Arab Emirates 
Five: Enhancement of capacity development of Nigeria companies

The Nigeria Content Development Monitoring Board (NCDMB), launched the \$200 million Intervention Fund (IF) with the Bank of Industry in 2017 solely to enable indigenous companies easily access fund for research and development to accelerate capacity development. About 20 Nigerian companies have benefitted from this fund and the result has been quite encouraging. Baring his mind on this issue, the Executive Secretary of NCDMB, Engr. Simbi Wabote had this to say:

Today, I can safely tell you that almost 85 percent of that fund has been accessed by Nigerian companies unlike most funds that they don't see people accessing them ... Nigerian companies have really developed their capacity and are doing heavy duty projects. For example, before the advent of the law itself, all fabrication works were done outside the country. But between now and then, like you know this year is the $10^{\text {th }}$ anniversary of the establishment of the board, Nigerian Companies are now fabricating 60,000 metric tonnes. This is quite substantial and today we are to integrate FPSO incountry; we are able to manufacture all the cables we use in the oil and gas sector; we are able to manufacture pipes and there have been tremendous achievements in terms of heavy duty activities $\left[{ }^{16}\right]$.

Still elaborating on the level of capacity development of Nigerian companies, Wabote stated:

The first integration facility in Africa was done here in Nigeria. And we integrated the largest FPSO in the world that is producing 200,000 barrels per day. So that is a huge achievement and it is heavy lift and we have been able to do that. The fund in itself is just galvanizing that process the more, but in terms of capacity, we have built substantial capacity... Today 75 percent of the contracts are awarded to Nigerian companies. Today, we have been able to fabricate, for instance, in the Egina FPSO, 70 percent of local content was done incountry. These are very clear statistics for everybody to see $\left[{ }^{17}\right]$.

\section{Six: Human capacity development of Nigerians}

The Nigerian Content Development Monitoring Board also strives to ensure that Nigerians enhance their capacity in terms of owing companies and being employed in existing companies unlike what it

\footnotetext{
${ }^{16}$ Nigerian Content Implementation now at new level with $1 \%$ Contractor's fund-Simbi Wabote', Vanguard, March 10, 2020. Online accessed 10/03/2020, 2.05pm$3.10 \mathrm{pm}$.

${ }^{17} \mathrm{Ibid}$
}

used to be. Again, Wabote throws light on this in an unambiguous language:

In terms of human capacity development, most of the indigenous operators companies are owned 100 percent by Nigerians. If you go today to a company like the NLNG, 95 percent of the staff in that organization are Nigerians. You go to Shell the same statistics. So it is everywhere for everybody to see. It's been a phenomenal success in the oil and gas sector in terms of local content $\left[{ }^{18}\right]$.

\section{Seven: Infrastructural development}

The local content policy of the Federal Government has impacted positively on infrastructural development in society, which among other services arising from such developments also enhances environment quality and aesthetics. For example, the high rise headquarters of the monitoring board and also a massive auditorium.

Talking about the success story on some infrastructural developments within the content development stride of the Nigerian government, Wabote enthused with contentedness when he declared:

When I came on board in 2016 November, they just finished the foundation of the headquarters building. Between that period and now, it is a short period to complete a 17 storey building. You know the antecedent of Nigerians in terms of project completion. Some projects have stayed for 15 years, NPDC headquarters in Benin is an example. But between 2016 and 2019 we completed the NCDMB headquarters ... like you know, it is the tallest building in the South-south and South-east put together. We have a 1000seater auditorium, which I think perhaps is the best auditorium in this country that is owned by government. We also have a four-storey car park. That project is thinking ahead in places like Bayelsa, where you never thought such project could come alive and having a carpark built. So we are ahead of our time in terms of our thought process on that project. By the grace of God, it is something one looks back and be happy with $\left[{ }^{19}\right]$.

While appreciating these progressive steps in the right direction in the local content development, yet one cautions that such enthusiasm should not be taken too far, for at least, two major reasons.

In the first place, we have not progressed to such a level as to be repairing and maintaining our refineries so as to be able to refine our crude oil locally and cease from importing refined petroleum for national

${ }_{18}^{18}$ Ibid.
${ }^{19}$ Ibid. 
consumption with its attendant capital flight by way of subsidy payment by the government. This incapacity on the part of Nigerians which make us dependant on expatriates for repairs and maintenance is responsible for the below capacity and epileptic production of our refineries. This point is brought out quite clearly by this editorial piece:

Nigeria's moribund refineries have purportedly gulped \$396.33 million in the professed efforts by successive governments to fix them for optimal production. But vacuity in the desired result has provoked an inquest in the House of Representatives. Despite being a major global crude producer, the country has for three decades been importing petroleum products. It is an inexplicable irony, evidence of abject leadership failure, which continually bleeds the public treasury and promotes inestimable corruption. The House Committee on Petroleum Downstream, chaired by Abdullahi Gaya, which visited the Warri and Port Harcourt refineries, discovered that the refineries had not undergone any turnaround Maintenance since 2004. A former Group Managing Director, Nigerian National Petroleum Corporation, Maikanti Baru, had earlier confirmed that TAM on the refineries had not been carried out in 42 years. This is curious! Every administration takes the repair of the four refineries as its cardinal policy, ostensibly to reposition the economy. Lack of vision and sound economic policies have stuck the country in this wasteful trajectory. Certainly, the lawmakers' investigation is not the first since the Fourth Republic began in 1999. Nevertheless, its objective of bringing to account those who spend public funds wastefully or enriched themselves in the process has never been achieved. This national gambling to fix obsolete refineries cost the country N99 billion in the twilight of Goodluck Jonathan's administration in 2015. The NNPC had used local engineers to repair them, after the original builders from Japan and Italy had turned down contractual offers to carry out their TAM. But the refineries broke down barely three months after. The overhaul, the authorities usually claim, will increase the refineries' capacity from 445,000 barrels per day to 700,000 barrels per day. In spite of the \$396 million expended on them, however, daily capacity utilization vacillates between 15 and 25 percent $\left[{ }^{20}\right]$.

The second point lies on the fact that we have not so much been committed to extensive and intensive research and development in the Oil and gas sector. Perhaps, we are still at the peripheral level of research and development. Until when we embrace the former without jettisoning the latter, the issue of transfer of technology may remain a mirage as no nation would voluntarily transfer her technology to another nation.

20 The Punch Editorial', Friday, April 3, 2020

(emphasis added).

(c) 2020 | Published by Scholars Middle East Publishers, Dubai, United Arab Emirates technological knowledge, and African countries must note this, ought to do is that such a country can look at what other technologically advanced nations have done and strive to emulate or adapt to it and possibly improve upon it. This is a vital point African nations must come to terms with if we ever think of making giant strides in acquisition of technological knowledge in this contemporary and competitive age. The view of Simbi Wabote aptly reinforces this point when he expressed thus:

But are we able to adapt to technology as fast as it is growing? The answer is probably no because I don't think as a country we are investing heavily on $R \& D$. Because we are not doing that we will continue to do catch-up. Nobody is going to transfer technology to you, it is never done. Transfer of technology is a myth as far as I am concerned, but adaptation of technology is a possibility. But if you don't invest in research and development in this sector, then you will continue to play second fiddle and I don't think as a country, we have paid great attention to research and development in the oil and gas sector... The other bit again is that if you google and look at annual spending in each country on research and development, there is no African country on that list apart from South Africa that spent 0.02 percent of its GDP on research and development. No other African country. Little wonder we are still a third world country because we are not really investing in $R \& D$ $\left[{ }^{21}\right]$.

\section{CONCLUSION}

Even though some progress has been recorded in achieving the objectives of the Local Content Act, a lot more is yet to be achieved. This is moreso when we still depend on experts from abroad for even the maintenance of our oil refineries.

\section{RECOMMENDATIONS}

If the objectives of the Act would be achieved within reasonable time, the following are recommended:

Firstly, there should be aggressive monitoring and implementation/ enforcement of the provisions of the Act within the industry by the appropriate authorities, particularly the Content Monitoring Board. This is to ensure diligent and progressive implementation and achievement of the overall intendment of the Act.

Secondly, areas where indigenous Nigerians should understudy expatriate personnel are strictly
21 Ibid. 
implemented by ensuring that such understudy is in place. This is to enable succession contemplated under the Act.

Thirdly, the need to put those Nigerians already trained in skill acquisitions to demonstrate their expertise under the examination and monitoring by experts to assess their proficiency is urgent. These groups of individuals have so much to do in the area of achieving technology transfer.

Again, where those graduates in skill acquisition fail to demonstrate mastery of their areas of specialization arising from the demonstration test preceding above, there should be the need for a refresher course, even at the expense of the appropriate agency of the government. This is to enhance in-depth knowledge and mastery of areas of specialization in order to effectively impact in the industry.

Finally, developing nations must aggressively invest in research and development in an extensive and intensive manner if only to make the long dream of technology transfer a reality.

It is believed that if the above recommendations, among others, are carried out, they will contribute in no small measure in achieving the overall objectives of the Local Content Act in Nigeria. 